\title{
Cultural and morphological studies on Ponnampet leaf and neck blast isolates of Magnaporthe grisea (Herbert) barr on rice (Oryza sativa L.)
}

\author{
Kalavati Teli*, M.K. Prasannakumar, V. Jyothi, S.C. Chandrashekar, M. Bhagyashree, \\ M. Raviteaz and N. Amrutha
}

Department of Plant Pathology, University of Agricultural Sciences, Gandhi Krishi Vigyan Kendra, Bengaluru - 560065 (Karnataka), INDIA

*Corresponding author. E-mail: agriunit.kalavati@gmail.com

Received: July 8, 2015; Revised received: February 2, 2016; Accepted: April 11, 2016

\begin{abstract}
The study was carried out to standardize the optimal growth, sporulation and production of perfect stage of pathogen on different media. Among different media used such as Potato dextrose Agar (PDA), Oat meal Agar, Ragi flour agar, yeast extract $+2 \%$ soluble starch, Host extract $+2 \%$ soluble sucrose agar, Potato dextrose agar + Biotin + Thiamine and Rice flour agar, Oat meal agar and potato dextrose agar was found to be best media for radial growth and sporulation of $M$. grisea. Maximum conidia length $(9.46 \mu \mathrm{m})$ and breadth $(7.36 \mu \mathrm{m})$ was recorded in Oat meal agar followed by Potato dextrose agar and least conidia length $(6.15 \mu \mathrm{m})$ and breadth $(5.11 \mu \mathrm{m})$ was recorded in ragi flour media after 20 days of inoculation. Conidial size varied in leaf and neck blast isolates, the maximum mean colony diameter of $88.00 \mathrm{~mm}$ and $89.16 \mathrm{~mm}$ in neck and leaf blast was recorded in Oat meal agar respectively. The maximum sporulation mean index was observed in Oat Meal agar of $3.15 \mu \mathrm{m}$ in leaf and $3.20 \mu \mathrm{m}$ in neck blast was recorded. The best growth of the pathogen was recorded at optimum pH range from $6.0-7.0$ and temperature of $27^{\circ} \mathrm{C}$. Therefore oat meal agar media was found to be best among all the media used for growth, sporulation, conidial size and colony characters of $M$. grisea.
\end{abstract}

Keywords: Blast, Fungus, Isolates, Resistance, Rice

\section{INTRODUCTION}

Rice (Oryza sativa L.) is one of the most important cereal crop of the family Poaceae. Presently the rice production is insufficient to cover the needs and hence several countries have been importing rice. In 2008, Sub-Saharan Africa imported more than US \$ 3.6 billion worth of rice, mainly from Asia, to fill the gap between production and consumption. India is the largest rice growing country accounting for about one third of the world acreage under the crop. Rice crop occupies about 44.3 mha in the country with a record production of $103.41 \mathrm{mt}$ and productivity of $2125 \mathrm{~kg} /$ hectare as estimated during 2011-12. However, in Karnataka rice is cultivated in about 15.39 lakh hectare with an annual production of 42.97 lakh tonnes and productivity of $2938 \mathrm{~kg} /$ hectare during the year 2010 11 (Anonymous, 2011). Rice suffers from many diseases caused by fungi, bacteria, viruses, phytoplasma, nematodes and other non-parasitic disorders. Among the fungal diseases, blast is considered as a major threat to rice production because of its wide spread distribution and its destructiveness under favourable conditions. Losses due to the blast disease may range up to $90 \%$ depending upon the component of the plant infected (Padmanabhan, 1963).
M. grisea infects above ground parts of the plant, but neck blast and the panicle blast are the most damaging phases of the disease and have been shown to significantly reduce yield, grain weight and milling quality. A typical blast lesion on a rice leaf is gray at the centre, has a dark border and it is spindle-shaped. Under favourable conditions, leaf lesions enlarge and coalesce, eventually blighting the entire leaf. Neck blast results in a girdled neck with grayish brown lesions (Pinnschmidt et al., 1994). The report of the perfect stage of a non-pathogenic species of Pyricularia (Webster, 1965) lead to the possibility of the successful development of perithecia in pathogenic species of Pyricularia. The formation of perfect stage of Pyricularia grisea was observed in culture media by mating two isolates of blast fungus obtained from crabgrass (Digitaria sanguinalis (L.) Scopoli) (Hebert, 1971). Therefore in this study, the extensive work was carried out to standardize the optimal growth, sporulation and production of perfect stage of pathogen on different media.

\section{MATERIALS AND METHODS}

Collection and isolation of the fungus: Infected leaf and neck plant samples collected from Ponnampet during kharif 2011 were used for isolation of 


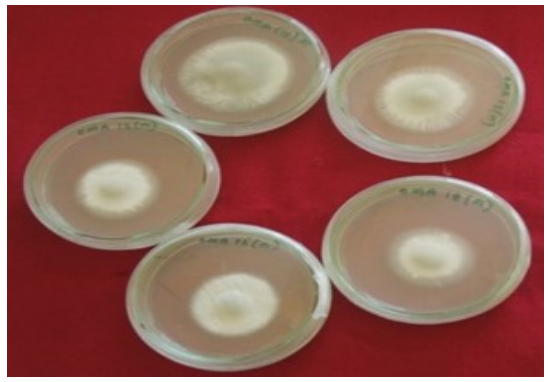

Oat Meal Agar (Himedia)

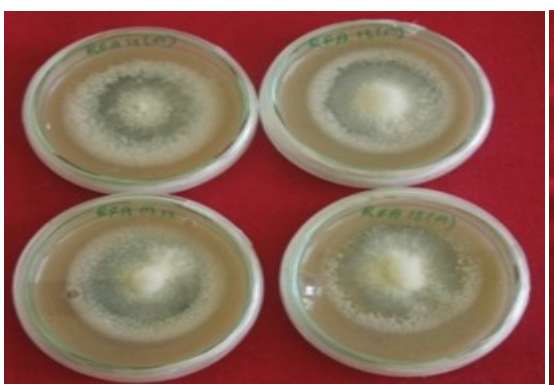

Ragi flour agar

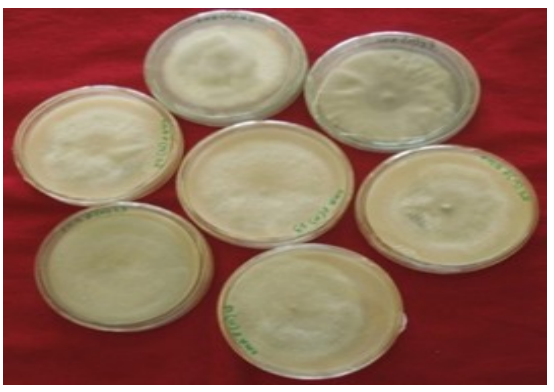

Oat Meal Agar

Fig. 1. Magnaporthe grisea leaf isolate (Ponnampet) culture on different media.

Table 1. Criteria used to index the sporulation frequency of M. grisea.

\begin{tabular}{lcc}
\hline Sporulation & $\begin{array}{c}\text { No. of spores/ micro- } \\
\text { scopic field }\end{array}$ & Index \\
\hline Excellent & $>30$ & 4 \\
Good & $20-30$ & 3 \\
Fair & $10-20$ & 2 \\
Poor & $<10$ & 1 \\
Nil & 0 & 0 \\
\hline
\end{tabular}

Magnaporthe oryzae by following the standard tissue isolation technique. The infected leaf and neck portions were split open longitudinally with the help of sterilized scalpel and washed well with running tap water. These bits were surface sterilized with 1: 1000 mercuric chloride $\left(\mathrm{HgCl}_{2}\right)$ solution for $30 \mathrm{sec}$ and washed three times in sterile distilled water before transferring them to oat meal agar plates. They were incubated at $28 \pm 1^{\circ} \mathrm{C}$ for two weeks.

Monoconidial isolation: This method was followed for maintaining pure culture of $M$. oryzae, since the fungus is heterokaryotic in nature. Hyphal tip isolation for the leaf isolates was done on 2 per cent water agar plates. Well developed lesions were identified, excised and washed in running water for $2 \mathrm{hrs}$. The leaf bits were surface sterilized with mercuric chloride then washed serially with sterile double distilled water and allowed for sporulation on sterilized glass slides by incubating in a moist chamber at $28^{\circ} \mathrm{C}$ for $48 \mathrm{hrs}$. Well sporulated lesions were placed in double distilled water in the test tubes and vortexed for $1 \mathrm{~min}$. About $1 \mathrm{ml}$ of spore suspension was added to sterilized plates and $2 \%$ agar was added. Single spores were located and picked up microscopically. Each spore was eventually transferred to potato dextrose agar slants. The slants were incubated at $28^{\circ} \mathrm{C}$ for 2 days and stored at $4^{\circ} \mathrm{C}$ in refrigerator.

Maintenance of isolates of Magnaporthe grisea: Pure culture of $M$. grisea so obtained from hyphal tip isolation method was sub cultured on Oatmeal agar slants and kept at $28 \pm 1{ }^{\circ} \mathrm{C}$ for 15 days. Subsequently sub culturing of isolates was done at an interval of 20 days. Such slants were stored in a refrigerator at $5^{\circ} \mathrm{C}$. The culture was renewed every two months.

Pathogenicity test: Pathogenicity test was carried out to confirm the ability of the fungus in culture to produce typical symptoms of the disease under artificial conditions on rice leaves of healthy plants. The susceptible paddy variety (HR-12) was sown in sterilized soil. At seedling stage, they were sprayed with spore suspension obtained from culture of M. grisea grown

Table 2. Cultural characteristics of $M$. grisea on different media.

\begin{tabular}{|c|c|c|c|c|}
\hline Media & Isolate colour on media & Growth & Margin & Sporulation \\
\hline Oat meal agar & Off white & Good and uniform & Smooth & Excellent \\
\hline $\begin{array}{l}\text { Potato dextrose agar } \\
\text { medium }\end{array}$ & $\begin{array}{l}\text { Dull brown in the centre and gray } \\
\text { white at margins }\end{array}$ & Good and uniform & Smooth & Good \\
\hline Ragi flour medium & $\begin{array}{l}\text { Light grayish brown in the centre and } \\
\text { grey white at margins }\end{array}$ & Good and uniform & Irregular & Poor \\
\hline $\begin{array}{l}\text { Yeast extract } \\
+2 \% \text { soluble starch }\end{array}$ & $\begin{array}{l}\text { Dull brown in the centre and gray } \\
\text { white at margins }\end{array}$ & Good and uniform & Irregular & Poor \\
\hline
\end{tabular}

Table 3. Colony characteristics of Ponnampet leaf and neck blast isolates of $M$. grisea on different media.

\begin{tabular}{|c|c|c|c|}
\hline \multirow{2}{*}{ S. N. } & \multirow{2}{*}{ Media } & \multicolumn{2}{|l|}{ Colony characters } \\
\hline & & Leaf isolate & Neck isolate \\
\hline 1 & Oat meal agar & $\begin{array}{l}\text { Buff colour, smooth margin and good } \\
\text { growth }\end{array}$ & $\begin{array}{l}\text { Buff colour, irregular margin, concentric ring } \\
\text { pattern and good growth }\end{array}$ \\
\hline 2 & $\begin{array}{l}\text { Potato dextrose agar } \\
\text { medium }\end{array}$ & $\begin{array}{l}\text { Grayish black colour, irregular margin } \\
\text { and good growth }\end{array}$ & Buff colour, smooth margin and good growth \\
\hline 3 & Ragi flour medium & $\begin{array}{l}\text { Black colour, smooth colony margin } \\
\text { and poor growth }\end{array}$ & $\begin{array}{l}\text { Greyish black colour, smooth colony margin } \\
\text { and good growth }\end{array}$ \\
\hline 4 & $\begin{array}{l}\text { Yeast extract } \\
+2 \% \text { soluble starch }\end{array}$ & $\begin{array}{l}\text { Black colour, irregular margin and } \\
\text { good growth }\end{array}$ & $\begin{array}{l}\text { Buff white colour, irregular margin and } \\
\text { medium growth }\end{array}$ \\
\hline
\end{tabular}


Table 4. Mean colony diameter of Ponnampet leaf and neck blast isolates of $M$. grisea on different media.

\begin{tabular}{|c|c|c|}
\hline \multirow{2}{*}{ Different media } & \multicolumn{2}{|c|}{$\begin{array}{l}\text { Colony diameter five } \\
\text { observation (mm) }\end{array}$} \\
\hline & Leaf blast & Neck blast \\
\hline Oat meal agar & 89.16 & 88.00 \\
\hline Potato dextrose agar & 74.63 & 73.50 \\
\hline Ragi flour medium & 60.60 & 58.30 \\
\hline $\begin{array}{l}\text { Yeast extract }+2 \% \text { solu- } \\
\text { ble starch }\end{array}$ & 57.56 & 55.00 \\
\hline Mean & 70.48 & 68.7 \\
\hline $\operatorname{SEm} \pm$ & 0.54 & 0.58 \\
\hline $\mathrm{CD}$ at $1 \%$ & 1.63 & 1.78 \\
\hline
\end{tabular}

Table 5. Sporulation index of Ponnampet Leaf and neck blast isolates of $M$. grisea on different solid media.

\begin{tabular}{lll}
\hline \multirow{2}{*}{ Different media } & \multicolumn{2}{l}{$\begin{array}{l}\text { Sporulation (Mean index of five } \\
\text { observations) }\end{array}$} \\
\cline { 2 - 3 } & Leaf & Neck \\
\hline Oat meal agar & 3.15 (27 spores) & $3.20(29$ spores $)$ \\
$\begin{array}{l}\text { Potato dextrose } \\
\text { agar medium }\end{array}$ & 2.83 (18 spores) & 2.88 (20 spores) \\
$\begin{array}{l}\text { Ragi flour me- } \\
\text { dium }\end{array}$ & 1.77 (16 spores) & $1.72(18$ spores $)$ \\
$\begin{array}{l}\text { Yeast extract+ } \\
\text { 2\% soluble starch }\end{array}$ & 0.00 & 0.00 \\
\hline
\end{tabular}

on oat meal agar. Control plants were maintained for which no inoculum was added. Inoculated plants were covered with polythene bags to ensure high humidity and periodical observations were made for the development of symptoms. Re-isolations were made from infected plants and cultures thus obtained were compared with original cultures to confirm identity of the pathogen.

Morphological and cultural variations among the leaf and neck blast isolates of $M$. grisea

Morphological variability: Spores of $M$. grisea of

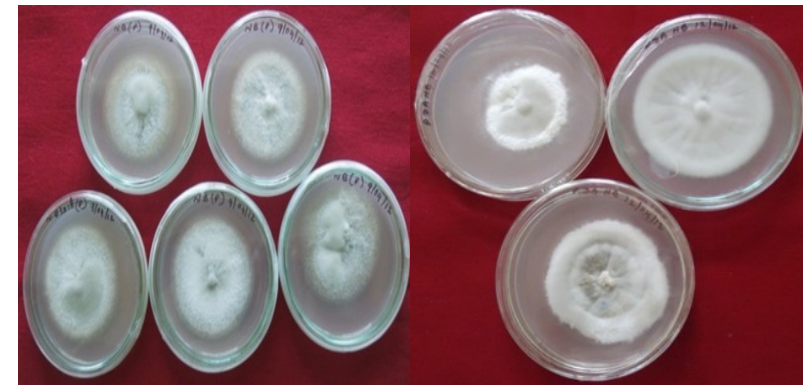

Oat meal agar (Himedia)

Potato dextrose agar

Fig. 2. Magnaporthe grisea neck isolate (Ponnampet) culture on different media.

leaf and neck isolates were measured directly from the infected host tissue mounted in lactophenol on a clean slide. Spores were mixed with lactophenol thoroughly so that, a uniform spread is obtained and then a cover slip was placed over it. Spores were measured under high power objective (40x) using ocular and stage micrometer. The average size of spore was then determined and shape of the spores were recorded. Microphotographs were taken to show the typical spore morphology of the pathogen.

\section{Cultural variation}

Growth characters on solid media: The growth characters of and neck isolates were studied on four solid media viz., Yeast extract $+2 \%$ soluble starch, Oat meal agar, Potato dextrose agar and Ragi flour agar medium. Fifteen $\mathrm{ml}$ of each of the medium was poured into each of sterilized Petri plates. Inoculation was made by transferring the five $\mathrm{mm}$ disc of mycelial mat, taken from the periphery of 10 days old culture. Each treatment was replicated thrice. The plates were incubated at $27 \pm 1^{\circ} \mathrm{C}$. Observation on colony radial growth was taken when the maximum growth was attained in any one of the media tested. Other cultural characters viz., rate of growth, type of margin, colony colour and sporulation were also recorded. The composition and procedures for preparation of the media used in this experiment were followed as explained by Ainsworth (1971) and Tuite (1969).

Sporulation variation: The sporulation capacity of isolate on different media was assessed by microscopic observations. A loopful of culture was transferred to a

Table 6. Spore morphometry of Ponnampet leaf and neck blast isolates of $M$. grisea on different media.

\begin{tabular}{llccc}
\hline \multirow{2}{*}{ Different media } & \multicolumn{2}{c}{ Measurement of leaf and neck blast conidia of five observations $(\boldsymbol{\mu m})$} \\
\cline { 2 - 5 } & \multicolumn{2}{c}{ Leaf blast spore } & Neck blast spore \\
\cline { 2 - 5 } & Length & Breadth & Length & Breadth \\
\hline Oat meal agar & 9.60 & 7.30 & 9.46 & 7.36 \\
Potato dextrose agar & 8.63 & 6.75 & 8.53 & 6.81 \\
Ragi flour medium & 6.83 & 5.76 & 6.15 & 5.11 \\
Mean & 8.35 & 6.60 & 8.04 & 6.42 \\
SEm \pm & 0.82 & 0.50 & 0.86 & 1.12 \\
CD at $1 \%$ & 2.49 & 1.52 & 2.61 & 3.37 \\
\hline
\end{tabular}


clean slide and mixed well with lactophenol and a cover slip was placed on it. The Criteria used to index the sporulation frequency was followed as per the standard technique given by Henry and Andersen (1948) as below (Table 1).

\section{RESULTS AND DISCUSSION}

The identification of fungal pathogen in the present study as M. grisea was based on the principal morphological and cultural characters as described by Nishikado (1926). The typical blast symptoms were observed on 10th day after inoculation. The initial leaf blast symptoms appeared as small, water soaked, greyish dots which subsequently enlarged into spindle shaped spots with greyish white centre with a brown margin. In case of neck blast, the panicle infected was blackened and shrivelled leading to chaffy earhead in early stage. Later, panicle hanged down at the neck. In case of nodal blast, infected nodes turned black. The symptoms observed are in accordance with the description of Manibhushan Rao (1994) and Srivastava et al. (2014).

Cultural characteristics studied on different media to find out the variation for the growth and sporulation of leaf and neck blast isolates. Among the different media $M$. grisea grown on Oat meal agar showed good and uniform growth with smooth margin and excellent sporulation. While in case of Ragi flour medium and Yeast extract $+2 \%$ soluble starch medium the $M$. grisea growth was good and uniform but there was poor sporulation (Table 2).

The isolates were grown on different media like, oat meal agar, potato dextrose agar, ragi flour medium and yeast extract $+2 \%$ soluble starch. On the basis of morphological features like Buff colour colony with irregular margin, concentric ring pattern and medium to good growth the fungus was characterised and identified as M. grisea (Table 3 and Fig $1 \& 2$ ). Similar results were recorded by Srivastava et al. (2014) where various isolates of $M$. grisea produced ring like, circular, irregular colonies with rough and smooth margins on oat meal agar media having buff color, grayish black to black color. Ou, (1985a) recorded colony colour as greyish black to dark jet black color, smooth to irregular margin, medium to good growth of the pathogens on oat meal agar media.

In case of leaf blast, the maximum mean colony diameter was recorded in Oat meal agar $(89.16 \mathrm{~mm})$ followed by Potato dextrose agar $(74.63 \mathrm{~mm})$ and minimum colony diameter was observed in Yeast extract $+2 \%$ soluble starch $(57.56 \mathrm{~mm})$. In case of neck blast, the maximum mean colony diameter was recorded in Oat meal agar $(88.00 \mathrm{~mm})$ followed by Potato dextrose agar $(73.50 \mathrm{~mm})$ and minimum colony diameter was observed in Yeast extract $+2 \%$ soluble starch $(55.00 \mathrm{~mm})$ (Table 4). The similar results were obtained by Awoderu et al. (1991) and Getachew Gashaw et al. (2014) which showed that Oat meal

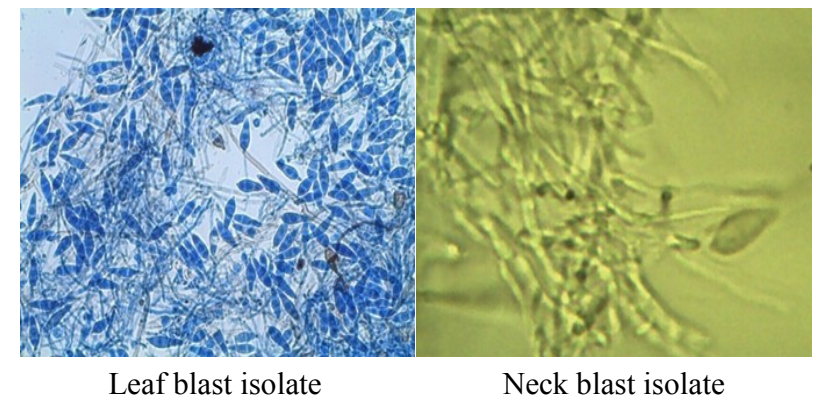

Fig. 3. Photomicrograph of mycelium and conidia of leaf and neck blast isolates.

agar and Richard Agar media had maximum mycelial growth of $P$. grisea with $87.3 \mathrm{~mm}$ and $88.2 \mathrm{~mm}$ in isolates of $\mathrm{Pg} 41$ and $\mathrm{Pg} 26$, respectively.

In case of leaf blast isolate, the maximum sporulation mean index was observed in Oat Meal agar $(3.15 \mu \mathrm{m})$ followed by Potato Dextrose Agar $(2.83 \mu \mathrm{m})$ and minimum sporulation was observed in ragi flour media $(1.77 \mu \mathrm{m})$ and there was no sporulation on yeast extract $+2 \%$ Soluble starch (Fig 3). In case of neck blast isolate, the maximum sporulation mean index was observed in Oat Meal agar $(3.20 \mu \mathrm{m})$ followed by Potato Dextrose Agar $(2.88 \mu \mathrm{m})$ and minimum sporulation was observed in ragi flour media $(1.72 \mu \mathrm{m})$ and there was no sporulation on yeast extract $+2 \%$ Soluble starch (Table 5). Similarly, Arunkumar and Singh (1995) reported good growth and sporulation of 2.95 $\mu \mathrm{m}$ in leaf blast and $3.00 \mu \mathrm{m}$ in neck blast in oat meal agar followed by host extract agar media. The isolates varied in their ability to grow and sporulate on different media. Same results were recorded by Sun guochang and Sun shuyuan (2001) cornmeal and rice straw agar medium supported maximum sporulation of the rice blast fungus. Rice leaf and potato agar medium, rice straw agar medium and oatmeal agar medium were also found to be effective.

Studies on morphological character of different isolates of $M$. grisea revealed the variation with respect to conidial size. $M$. grisea isolated from leaf region was grown on three different media. From each medium, six plates were selected and in each plate $M$. grisea spore morphometry was recorded. Maximum conidia length $(9.6 \mu \mathrm{m})$ and breadth $(7.3 \mu \mathrm{m})$ was recorded in Oat meal agar followed by Potato dextrose agar and least conidia length $(6.83 \mu \mathrm{m})$ and breadth $(5.76 \mu \mathrm{m})$ was recorded in ragi flour media. The observation was recorded 20 days after inoculation.

Whereas slightly small conidial size was observed in neck blast isolate $(9.46$ and $7.36 \mu \mathrm{m})$. However, no variation with respect to conidial shape was noticed where conidia was pyriform, almost hyaline to pale olive, 2-septate, 3-celled (Table 6). These results are in agreement as described by Shirai (1896) who recorded that, mycelium in cultures was first hyaline in colour, then changed to olivaceous, $1-5.2 \mu \mathrm{m}$ in width, septate and branched. The spore measurements were 
$15-22 \mu \mathrm{m} \times 4-7 \mu \mathrm{m}$ (Average, $17.4 \mu \mathrm{m} \times 5.2 \mu \mathrm{m}$ ). These results are also in confirmation with Meena (2005) and Getachew et al. (2013) where in all the isolates, the shape of the conidia was typically pyriform with base rounded, apex narrowed, 2-3 septate, 24 celled, and middle cells were broader than others in fingermillet crop. Existence of variability among the isolates of $P$. grisea with respect to conidial size ie., the average length of the isolate ranged from 21.2 to $28.4 \mu \mathrm{m}$, and the average width from 7.3 to $9.0 \mu \mathrm{m}$ which was well documented by many workers also (Aoki, 1935., Tochinai and Shimamura, 1932). The isolates of fingermillet Pg.41 and Pg.40 had the longest conidia of $26.91-35.43 \mu \mathrm{m}$ and $24.36-29.48 \mu \mathrm{m}$ respectively. The lowest conidial length was for isolates Pg.22 of $15.66-24.37 \mu \mathrm{m}$ and Pg.20 of $18.01-$ $24.03 \mu \mathrm{m}$. Highest conidial width was observed for isolates Pg.40 and Pg.22 with 8.35-11.92 $\mu \mathrm{m}$ and 7.70$12.90 \mu \mathrm{m}$ respectively as reported by Getachew Gashaw et al. (2014).

\section{Conclusion}

M. grisea grown on Oat meal agar showed good and uniform growth with smooth margin and excellent sporulation. While in case of Ragi flour medium and Yeast extract $+2 \%$ soluble starch medium the $M$. grisea growth was good and uniform but there was poor sporulation.In Spore morphometry study, the size of conidia was $9.6 \times 7.3 \mu \mathrm{m}$ on Oat meal agar and least conidial size of $6.15 \times 5.11$ was recorded in ragi flour medium. The fungal radial growth of leaf isolate was maximum on Oat meal agar $(89.16 \mathrm{~mm})$ and minimum on Yeast extract $+2 \%$ soluble starch $(57.56 \mathrm{~mm})$. A similar trend was observed with neck isolate with $88.00 \mathrm{~mm}$ and $55 \mathrm{~mm}$ on Oat meal agar and Yeast extract $+2 \%$ soluble starch respectively. The maximum sporulation indices for leaf and neck blast isolates were $3.15 \mu \mathrm{m}$ and $3.20 \mu \mathrm{m}$ on Oat meal agar respectively. Therefore oat meal agar media found to give best results on growth, sporulation, conidial size and colony characters of $M$. grisea as compared to all other media used.

\section{REFERENCES}

Ainsworth. (1971). Ainsworth and Bisby's Dictnory of fungi, $6^{\text {th }}$ Ed. CMI. Kew.

Anonymous. (2011). All India Co-ordinated Rice Improvement Project. Quinquennial report. Univ. Agric. Sci. Bangalore. pp. 1-2.

Aoki, Y. (1935). On physiological specialization in the rice blast fungus, Pyricularia oryzae Br.Et. Cav. Ann. Phytopathol. Soci. Japan. 5: 107.

Arunkumar, K. and Singh, R.A. (1995). Differential response of Pyricularia grisea isolates from rice, finger millet and pearl millet to media, temperature, $\mathrm{pH}$ and light.
Indian J. Mycol. Pl. Pathol. 25: 238-242.

Awoderu, V.A. Esuruoso, O.F. and Adeosun, O.O. (1991). Growth and conidia production of rice NG -5 / IA -65 of Pyricularia oryzae Cav. In vitro. J. Microbiol. 31: 163-168.

Getachew Gashaw, Tesfaye Alemu and Kassahun Tesfaye. (2013). Evaluation of disease incidence and severity and yield loss of finger millet varieties and mycelial growth inhibition of Pyricularia grisea isolates using biological antagonists and fungicides in vitro condition. J. Appl. Biosci., 73: 5883- 5901.

Getachew Gashaw, Tesfaye Alemu1 and Kassahun Tesfaye. (2014). Morphological, physiological and biochemical studies on Pyricularia grisea isolates causing blast disease on finger millet in Ethiopia. J. Appl. Biosci., 74: $6059-6071$

Hebert, T.T. (1971). The perfect stage of Pyricularia grisea. Phytopathology. 61: 83-87.

Henry, B.W. and Andersen, A.L. (1948). Sporulation by Pyricularia oryzae. Phytopathology. 38 :265-278.

Manibhushan Rao, K. (1994). Rice Blast Disease. Daya Publishing House. Delhi.

Meena, B.S. (2005). Morphological and Molecular Variability of Rice Blast Pathogen Pyricularia grisea (Cooke) Sacc. M.Sc. Thesis. Dharwad University of Agricultural Sciences, Dharwad.

Nishikado, Y. (1926). Studies on rice blast disease. Bull. Bureau Agric, Ministry Agric. For. Japan. $15: 1-2$.

Ou S.H. (1985a). Rice Diseases (2nd edn). CABI Publishing. Wallingford. UK. 380 p. ISBN 0851985459.

Padmanabhan. (1963). Morphological Variability Among Various Isolates Of Magnaporthe Grisea Collected From Paddy Growing Areas Of Kashmir. Int. J. Pharmaceutical Sciences Review and Res. 8:90-92.

Pinnschmidt, H.O. Teng P.S. and Luo, Y. (1994). Methodology for quantifying rice yield effects of blast. In: Zeigler RS, Leong SA, Teng PS, editors. Rice blast disease. Wallingford, Oxon (United Kingdom): CAB International, Los Baños (Philippines): Int. Rice Res. Institute. p 381-408.

Shirai, M. (1896). Notes on plants collected in suruga, Totomi, yamato and kii. Botanical Magazine, Tokyo. 10: 111-114.

Srivastava, D. Shamim, Deepak Kumar, Pramila Pandey, Khan, N.A. and Singh, K.N. (2014). Morphological and Molecular Characterization of Pyricularia Oryzae Causing Blast Disease in Rice (Oryza sativa) from North India. Int. J. Scientific and Res. Publications. 4 (7): $2250-3153$.

Sun guochang and Sun shuyuan. (2001). Conditions for sporulation and preservation of conidia of rice blast fungus pyricularia grisea. Major Fungal diseases of Rice Recent Advances. p. 111-117.

Tochinai, Y. and Shimamura, M. (1932). Studies on the physiological specialization in pyricularia oryzae $\mathrm{Br}$. et. Cav. Ann. Phytopathol. Soc. Japan. 26: 60.

Tuite, J. 1969. Plant Pathological Methods Fungi and bacteria. Burgess Publishing, Minneapolis, MN.

Webster, J. (1965). The Perfect Stage Of Pyricularia Aquuatica. Trans. British Mycol. Soc. 489: 449-452. 